\title{
Extending the life-span of cultural heritage structures
}

\author{
Paolo Clemente ${ }^{1}$
}

Received: 28 February 2018/ Accepted: 8 March 2018/Published online: 14 March 2018

(C) Springer-Verlag GmbH Germany, part of Springer Nature 2018

\begin{abstract}
Monuments and historic buildings represent our historic heritage, the witnesses of the history that have arrived up to our age. We have inherited them from the previous generations, and it is our duty to preserve and to transfer them to the future generations. Therefore, we must preserve our cultural heritage from the natural ageing and the natural catastrophes, such as earthquakes. This can be done by means of a continuous monitoring and periodic controls, using non-destructive techniques. The recent applications of structural health monitoring to cultural heritage structures are introduced in this paper. They present some interesting cases, which are examples of good practise for the future.
\end{abstract}

Keywords Structural health monitoring - Experimental dynamic analysis · Cultural heritage

\section{Introduction}

Structures are usually designed to perform their function for a certain life time. This is usually assumed to be 50 years, which is the usual value for ordinary buildings. It is assumed equal to 100 years or more for special structures, such as long span bridges and plants.

What is the life time of a cultural heritage structure?

We do not know the nominal life time at the time of construction, when this concept likely did not exist, but we certainly would like it to be very long, tending to infinite. Actually, monuments and historic buildings represent our historic heritage, the witnesses of the history arrived up to our age. We have inherited them from the previous generations, and it is our duty to preserve and to transfer them to the future generations.

What do we have to protect the monuments from?

It is well known that the erosion related to wind and rain, as well as the daily and seasonal thermal cycles contributed to the natural ageing of the materials of exposed surfaces of any structures. This phenomenon is usually accelerated by the presence of pollution, especially in urban areas. As a result, the strength of the materials can

Paolo Clemente

paolo.clemente@enea.it

1 ENEA, Casaccia Research Centre, Via Anguillarese 301, 00123 Rome, Italy be immensely degraded and consequentially, a significant reduction of the static and seismic capacity of the structures. The deterioration process can be facilitated by vibration effects, such as those induced by the traffic [1]. Therefore, any structure becomes more and more vulnerable to natural catastrophes, especially to earthquakes. Seismic events in the past caused the definitive destruction of several monuments and historic buildings and, in some cases, of the disappearance of entire civilizations.

The described deterioration process is unfortunately quite common for monumental structures. As a matter of fact, most of them were built when there was no traffic issue and, in most cases, without accounting for horizontal actions, such as those due to earthquakes. On the other hand, also in buildings designed with seismic retrofit concept, the mentioned effects can be very dangerous.

In several cases, the existing structures are damaged by the works related to new adjacent buildings or roads around them. The case of the settlements due to the excavation for the foundations and/or the underground floors of an adjacent building is quite common.

The importance of the historical and archaeological sites imposes a big effort in their preservation, but this is not the only reason. They are good attractions for tourists and therefore are also important from an economic point of view. Furthermore, the presence of hundreds or thousands of people imposes severe controls and maintenance efforts to guarantee the conservation of these structures in conjunction with an acceptable level of safety. 
How can we preserve and/or improve the level of safety of monuments?

Historical buildings are often characterized by an irregular form, both in plan and in elevation, the lack of vertical joints and transversal braces, in-plane flexibility or absence of floor slabs, and shallow foundations. These characteristics make them very vulnerable even to moderate seismic events. Furthermore, the structural rehabilitation of historical buildings is quite delicate, and should aim at the protection of human life, but also of the historical and artistic testimony. The interventions should be non-invasive and reversible, that make use of materials compatible with the original ones and not to determine changes in the original structural concept [2].

It is worth noting that also the usual concept of smart structure, which dissipates the seismic energy by means of the damage accumulated during a seismic event, is not acceptable for monumental structures. Furthermore, inadequate interventions were often the cause of the collapses of cultural heritage buildings during earthquakes, but the absence of a suitable maintenance and/or improving interventions could be even worse, as demonstrated during the last earthquakes in Italy. The health conditions of several monuments do not allow avoiding or postponing significant structural strengthening interventions.

What should we do to extend the life time of cultural heritage structures? Two important factors should be accounted for: to know the history of the construction and its architectural and structural characteristics and managing the maintenance of the structure.

Cultural heritage structures were built in different ages, using different materials, whose mechanical characteristics are not known and are difficult to model, and using technologies, which are not used any more. Their geometry is often not known and inspections are difficult due to the complexity of reaching all the structural components, especially the foundations. Besides, secondary structural and non-structural elements could contribute significantly to support loads, but this contribution is very hard to evaluate. Obviously, to define a retrofitting intervention and/or a suitable maintenance programme, it is compulsory to know the "objects of interest" in detail. This is also an essential issue for the mathematical modelling [3].

For the second aspect, the usual maintenance procedures are the classic maintenance on request, which implies a retrofitting intervention only if a damage is already occurred, and the cyclic preventive maintenance, which is aimed to prevent any damage and is based on an evaluation of the optimum maintenance period. The worst disadvantage of the first approach is that the damage is already occurred and the maintenance works, if still possible, require the interruption of the use of the building or at least an important limitation to it, with obvious negative economic effects. The disadvantage of the second approach is the difficulty in the definition of the optimum maintenance period.

A suitable alternative is to use two levels of monitoring:

- The continuous monitoring, which is to be preferred, whenever possible;

- The periodic controls by means of non-destructive techniques, which should be done in any case for those tests that cannot be substituted by the online monitoring [4].

The first approach allows checking the health status of the structure and its components continuously. A continuous dynamic monitoring, for example, allows to record the effects of any vibration source, especially those due to earthquakes [5]. The final goal is the reduction of the damage and so of the maintenance works and costs, and the increase of the safety check level.

The basics and the most interesting applications of structural health monitoring in the preservation of cultural heritage structures have already been presented in previous papers and books [6-8]. The importance of the multidisciplinary approach is to be emphasized, as demonstrated especially by the studies carried out on impressive archaeological sites [9-14] and monumental structures $[15,16]$.

Interesting specific studies have been conducted on the conservation of ancient stones [17], the health status of ancient timber structures [18-20] and historical bridges $[21,22]$. The structural health monitoring is important also in the retrofitting process of heritage constructions [23] especially when using new technologies [24].

In March 2017, this Journal launched a call for papers on Structural Health Monitoring of Cultural Heritage Structures with the author of this paper as guest editor. Several proposals were received between July and September 2017. They were subjected to the usual review process. Only ten of them were accepted and published in the last three issues of the Journal. In the following the accepted and published papers are introduced. They present some interesting case studies, which are examples of good practise for the future.

\section{Examples of structural health monitoring of cultural heritage structures}

Clementi et al. [25], after an overview of the damage to cultural heritage structures occurred during the seismic events that struck Central Italy in October 2016, investigated the Podestà Palace and the Civic Tower located at Montelupone, in detail (Fig. 1). The main aim of the study was the determination of modal properties of these 


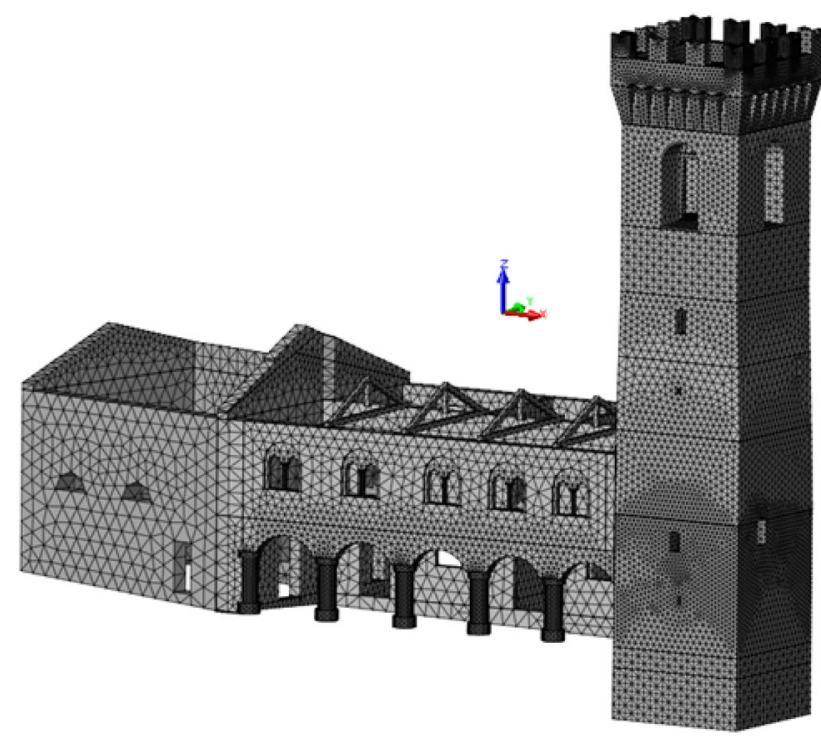

Fig. 1 The model of the Podestà Palace and the Civic Tower at Montelupone, Italy [25]

historical masonry constructions using experimental and numerical studies. The experimental analysis was based on ambient vibration survey. The results were used to tune a numerical model of the structure, with solid elements, which was used in the finite element analysis. The modulus of elasticity of masonry and the interaction among the structural portions, which were considered the most doubtful parameters, were adjusted to obtain a suitable consistency between the experimental results and the numerical ones. The study revealed the actual dynamic properties of the damaged palace.

The paper by Bongiovanni et al. [26] faces the problem of the preservation of tower structures, reporting the results of the study carried out on the Trajan's Column in Rome (Fig. 2). It was designed by Apollodorus of Damascus as a commemorative monument and decorated with reliefs that illustrate the two military campaigns of the Roman Emperor Trajan in Dacia (the modern Romania), between 101 and 102, and between 105 and 106 A.D., respectively. The experimental vibration analyses of the column carried out first in June 1985 and then in March 2012, were analyzed and compared in time and frequency domains. In both cases the main resonance frequencies were found, pointing out their reduction in the second campaign with respect to the previous campaign. Usually, these can be justified by non-linear effects related to the amplitude of the external actions. Instead, in this case the presence in the second campaign of horizontal loads lower than those of the first campaign did not allow considering this justification. In the March 2012 campaign, recordings were acquired for almost one day, with a certain temperature variation. A usual reduction of the amplitude of the motion was observed, but only a little variation of the main frequencies, which testifies a very little influence of the temperature on the dynamic behaviour of this structure.

Salonikios et al. [27] report the study of the Acheiropoietos basilica, an early Byzantine three-aisled timber roofed temple (Fig. 3), which suffered significant damage during the destructive earthquake of June 20th, 1978. Few years after the earthquake and before the interventions, ambient vibration measurements were performed on the structure and the main eigenfrequencies of vibration were obtained. The restoration project of the basilica, aiming to the provision of structural diaphragms at the level of the timber floors and roofs of the galleries, started at the middle of nineties. Horizontal steel frames were placed along the perimeter of the diaphragms at the wooden floors and wooden roofs. This intervention improved the seismic capacity of the temple. The efficiency of the intervention was checked by means of the analysis of the response of the structure to ambient vibration. The wooden diaphragms behaved as rigid floors, demonstrating that the intervention was implemented successfully.

Sciarretta et al. [28] present the results of the research and monitoring activities carried out at Palazzo Ducale in Venice, Italy, between 2009 and 2014 (Fig. 4). The aim of the study was to establish the structural health status of the two XIV-XV century external façades (South and West). The size of these façades, their complex and uncertain consistency, as well as their long and complicated history required a multidisciplinary approach with integrated and non-destructive methodologies. The diagnostics included the static monitoring of cracks and rotations, the dynamic monitoring along a critical vertical section, the sonic wave velocity measurements, the endoscopic probing and ground penetrating radar, the infrared thermographic imaging and the mineralogical and petro-physical analyses of stone samples. Other informations were obtained from visual and geometric surveys, bibliographic research and conventional calculations. The outcomes enlightened specific conclusions for each activity as well as crossing multidisciplinary points of view. These included the quality and consistency of the masonry, the stress state in the façade walls and the potentially critical issues. The study allowed optimizing the knowledge available. The results obtained could improve the scientific knowledge on the subject and support maintenance provisions for this unique and world-famous monument.

The historic complex of Santa Maria del Carrobiolo in Monza (Fig. 5), Italy, is the subject of the paper presented by Saisi et al. [29]. The study highlighted first that two sides of the bell-tower are directly supported by the loadbearing walls of the apse and South aisle of the neighbouring church. Then, a network composed of 10 
Fig. 2 Trajan's Column in Rome: a view and b Rondelet relief of the structure [26] (a)

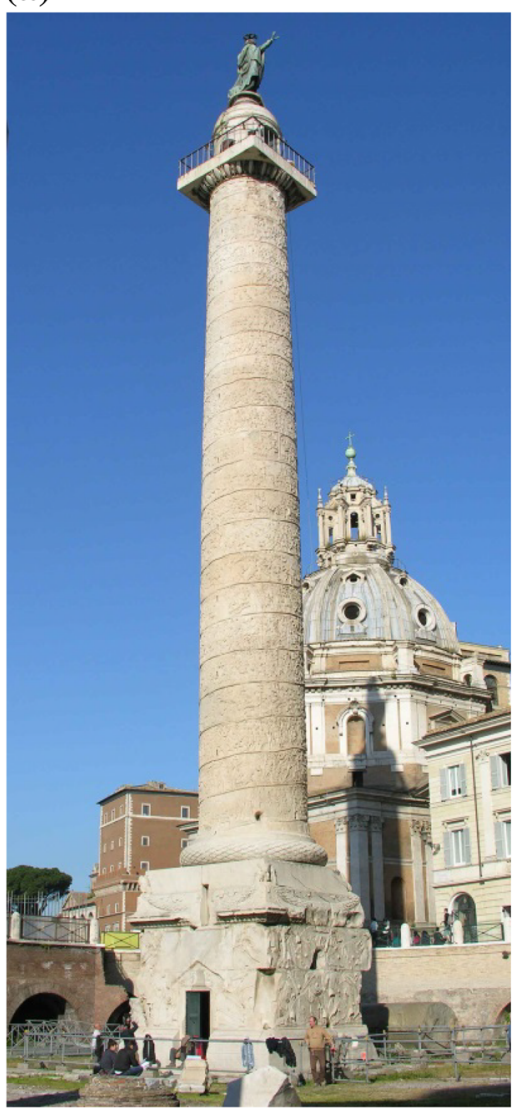

(b)

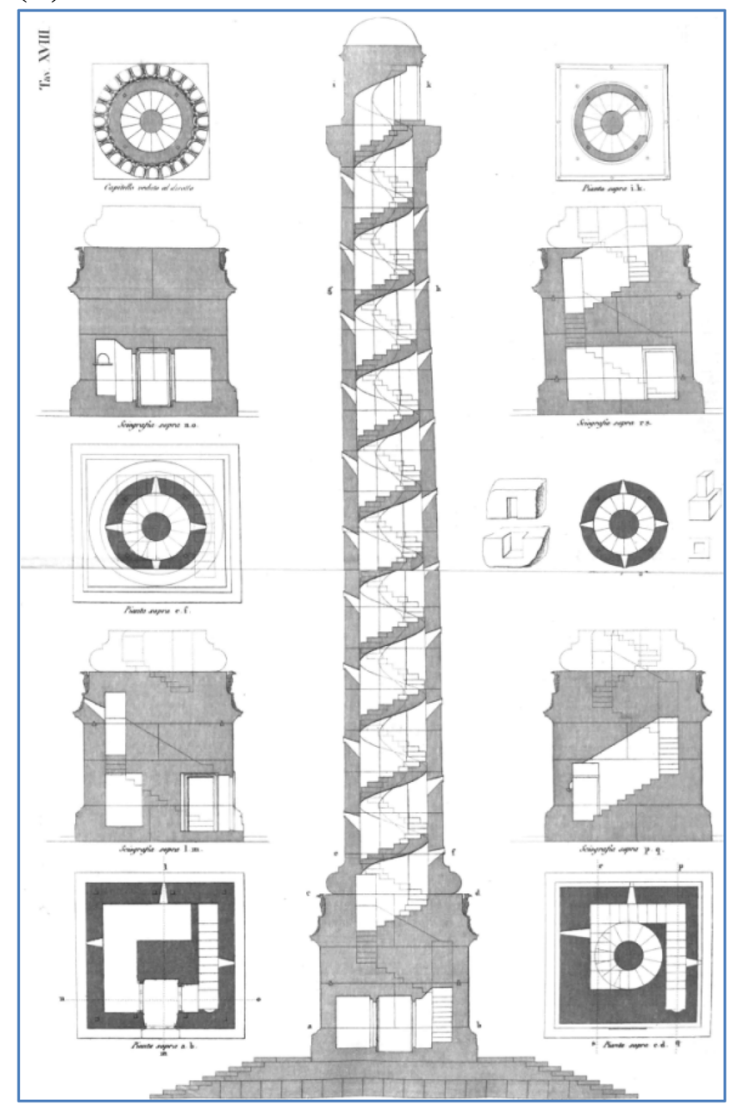

displacement transducers and 5 temperature sensors was installed in the tower to check the opening variation of the main cracks. Ambient vibration tests were performed and closely spaced modes with similar shapes were identified. Successively, a simple dynamic monitoring system was installed in the tower to complete the health monitoring aimed at the preservation of the historic structure. The paper focuses on the dynamic characteristics of the tower identified in the preliminary ambient vibration tests and on the main results obtained during 1-year dynamic monitoring. The effects of the temperature variation on the natural frequencies of the tower, which should be removed for an effective performance assessment, were assessed by means of simple correlation studies between modal frequencies and temperature.

Lorenzoni et al. [30] present the structural health monitoring activities performed on some representative cultural heritage buildings in L'Aquila, after the strong earthquake that struck the Abruzzo region on April 6th, $2009(\mathrm{Mw}=$ 6.3). Emergency activities started immediately after the earthquake to protect cultural heritage structures, including damage survey and design/implementation of temporary safety measures. Some historic buildings were soon equipped with monitoring systems to assess the level of damage and to verify the effectiveness of the provisional interventions. The paper focuses on two case studies, i.e., the Spanish Fortress and the Civic Tower in L'Aquila (Fig. 6). The results of the preliminary investigations are reported, including damage survey and operational modal analysis, i.e., the identification of modal parameters using ambient vibration tests. Data acquired for 3 years by continuous monitoring systems were processed using a datadriven approach, based on a regression analysis to filter out the environmental effects. From these data, static and dynamic monitoring features were extracted. Data were decomposed into their reversible and non-reversible components, the latter being associated to active damaging processes and the residual structural performance of the two buildings.

The archaeological site of Pompeii is the subject of the paper by Bergamasco et al. [31]. It is well known that the ancient Roman town of Pompeii was mostly destroyed and buried under a layer of 4-6 $\mathrm{m}$ of ash and pumice in the eruption of Mount Vesuvius in 79 AD, and that it remained covered until the beginning of archaeological excavations during the second half of the XVIII century. Nowadays, Pompeii Excavations is a UNESCO World Heritage Site and one of the most visited archaeological sites in the world. With the aim of preserving this archaeological heritage, the superintendence of the Pompeii 

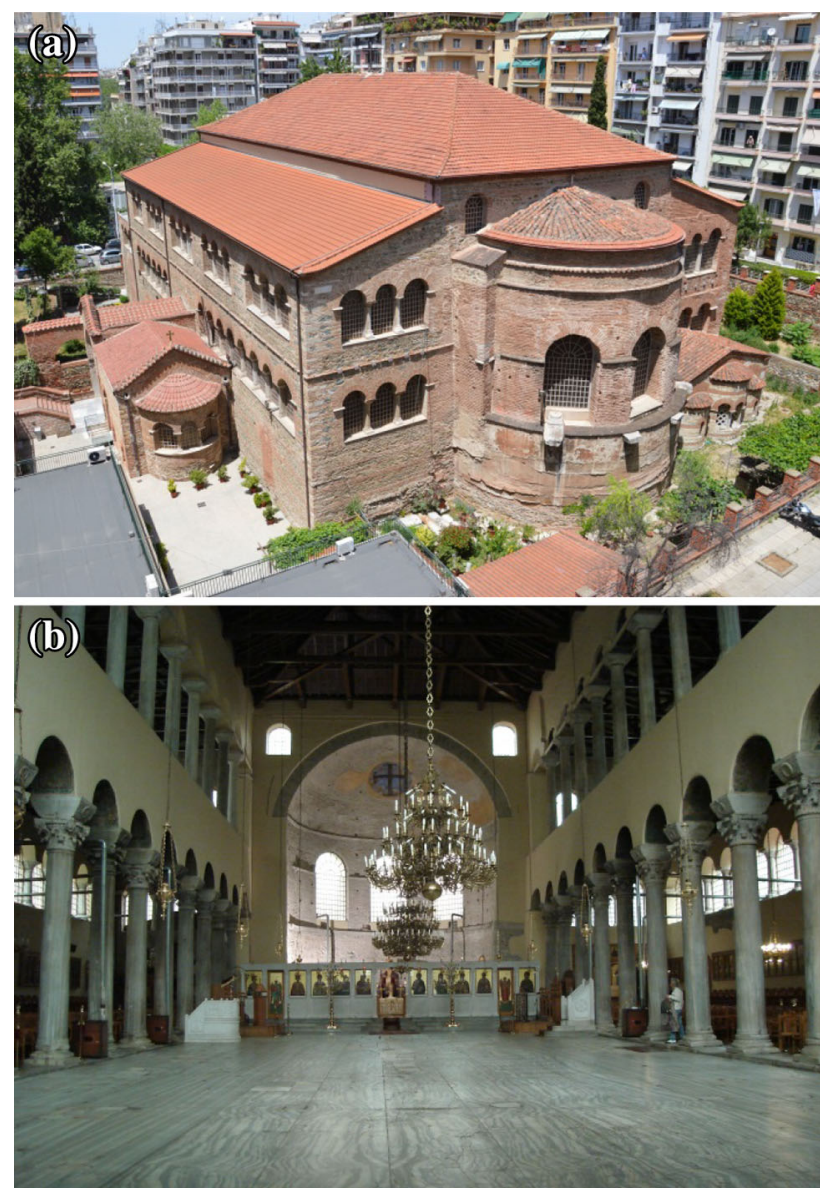

Fig. 3 a Southeast view and $\mathbf{b}$ internal view of the basilica Acheiropoietos [27]

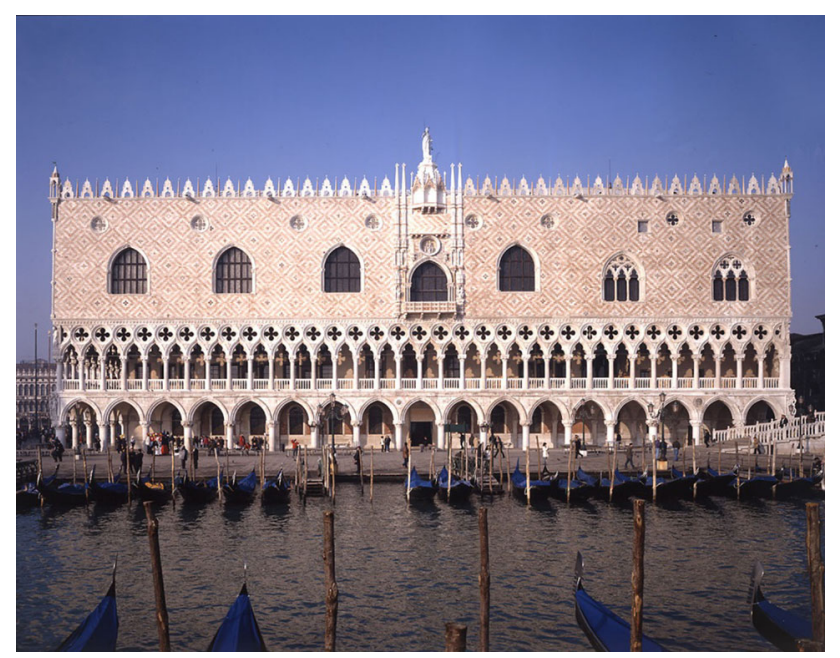

Fig. 4 Palazzo Ducale in Venice: the façade on San Marco basin [28]

Archaeological Park is directing various projects that involve many scientists and institutions. Within this framework, ENEA analysed the health status of the modern covering structures of Villa dei Misteri, which is an exceptionally well-preserved domus enriched by many precious frescos (Fig. 7). A research methodology, based on a multidisciplinary approach, was developed. This could become a qualified standard procedure of analysis to be used for all the similar roofing typologies, very common at Pompeii Excavations. The paper is focused on the in-depth diagnostic campaign carried out on the roof structures of the Peristilium. Both timber and reinforced concrete beams were fully analysed in two subsequent steps. In the first one, a visual and geometrical survey was carried out; in the second one, in situ non-destructive tests for the material characterization were performed. The analysis of the data obtained allowed the visual classification and the collection of useful information for the mechanical characterization. A proposal for the restoration intervention is also suggested.

Roselli et al. [32] report the results of the study carried out on the Ponte delle Torri at Spoleto, Italy (Fig. 8). The effects of the seismic sequence, which struck Central Italy from August 2016 to January 2017, on the structural health of the structure were analyzed by comparing the ambient vibration measurements before, during and after the seismic sequence. The changes in the dynamic characteristics of the structure were pointed out. They could be an index of the damage evolution. Environmental data were acquired simultaneously with the vibration ones, to account for the seasonal effects on the dynamic behavior. A preliminary finite element model allowed obtaining a first glance at the modal shapes and to choose the sensor locations. A more detailed model was set up after the recordings. High-resolution photos were obtained using an unmanned aerial vehicle and then a 3D reconstruction by structure-from-motion stereo-photogrammetry technique was done. The model was validated through comparison with the damage pattern experienced by the structure. Then, it was used to assess the seismic safety by means of both, non-linear dynamic and static pushover analyses.

Ferraioli et al. [33] report the most relevant results of the vibration-based investigations performed on a historic masonry tower in Italy, namely the Santa Maria a Vico bell-tower (Fig. 9). The first part of the study involves preliminary full-scale ambient vibration measurements in operational conditions and finite element modelling. A manual tuning of the uncertain parameters of the model was first carried out to adjust material properties, soilstructure interaction and constraining effects of the neighbouring structures. Then, a sensitivity analysis allowed choosing the updating parameters. Finally, a model updating technique, based on a sensitivity-based method, was used to minimise the error between the experimental vibration data and the numerical response values. The uncertain structural parameters of the finite element model were identified by minimising a robust penalty function. 
Fig. 5 Cross-section and fronts of the tower of Santa Maria del Carrobiolo in Monza, Italy [29]
Fig. 6 a The Spanish Fortress and $\mathbf{b}$ the Civic Tower in L'Aquila [30]
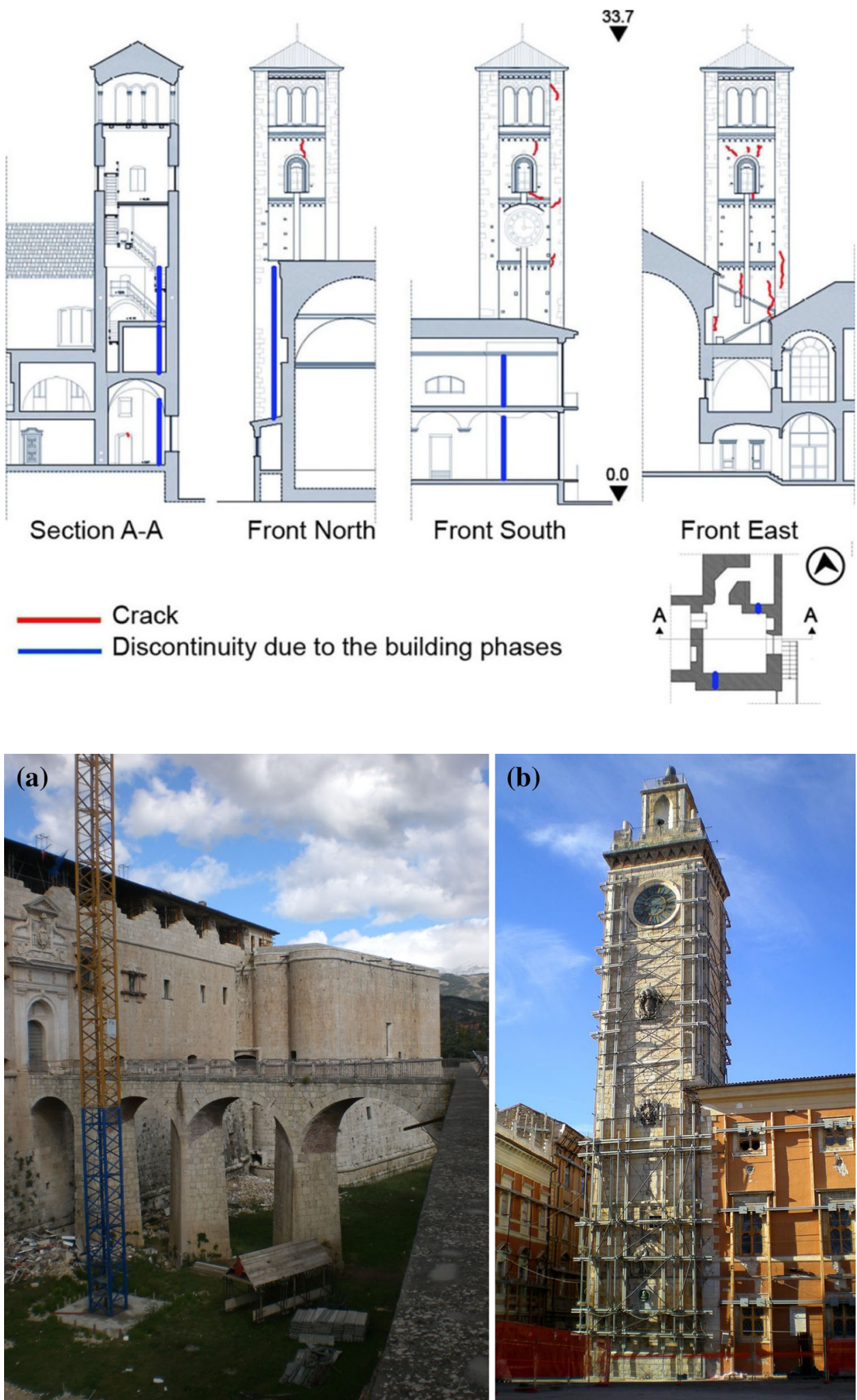

The calibrated model was used for the seismic assessment of the structure, which was performed by means of a pushover analysis. A sensitivity analysis was carried out for the masonry compression strength, considering reference values in the range of interest, which was the most sensitive parameter of non-linear behaviour. Finally, the seismic safety corresponding to increasing levels of the seismic hazard was investigated. 

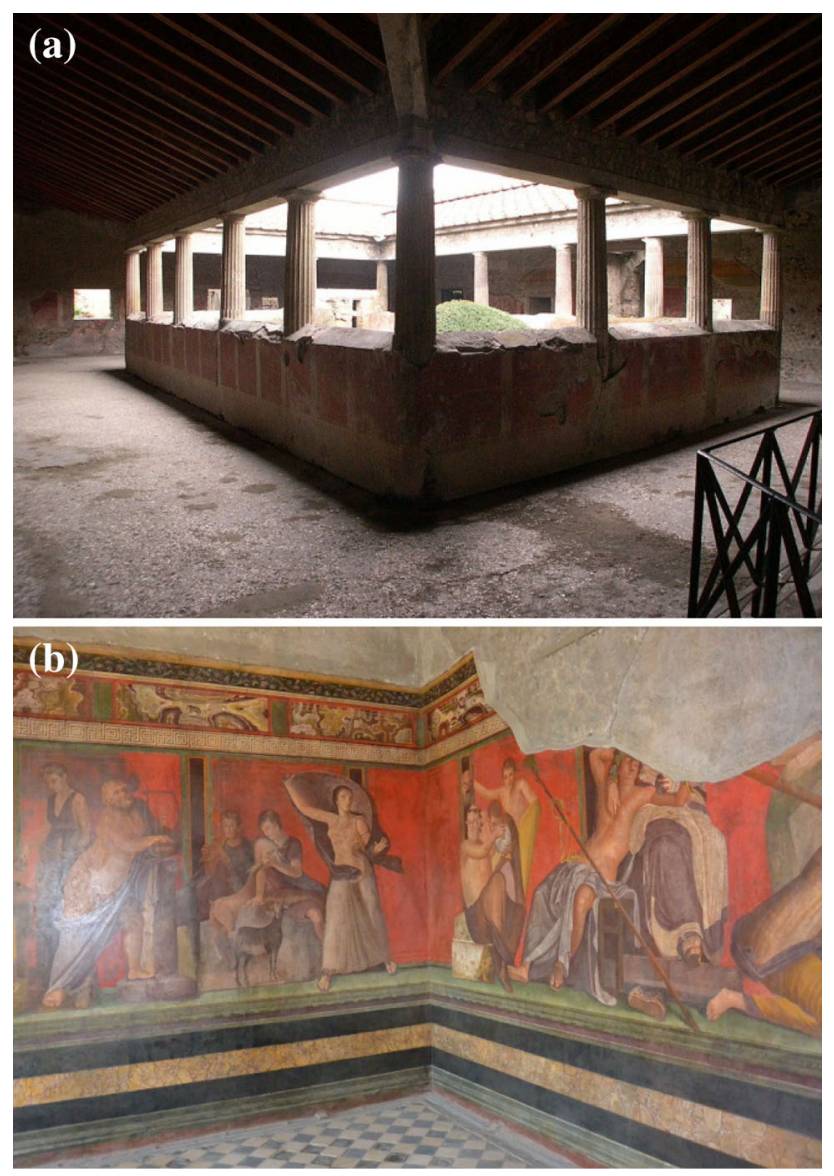

Fig. 7 a The Peristilium and $\mathbf{b}$ the superb painting cycle depicting a religious ritual in Villa dei Misteri at Pompeii, Italy [31]

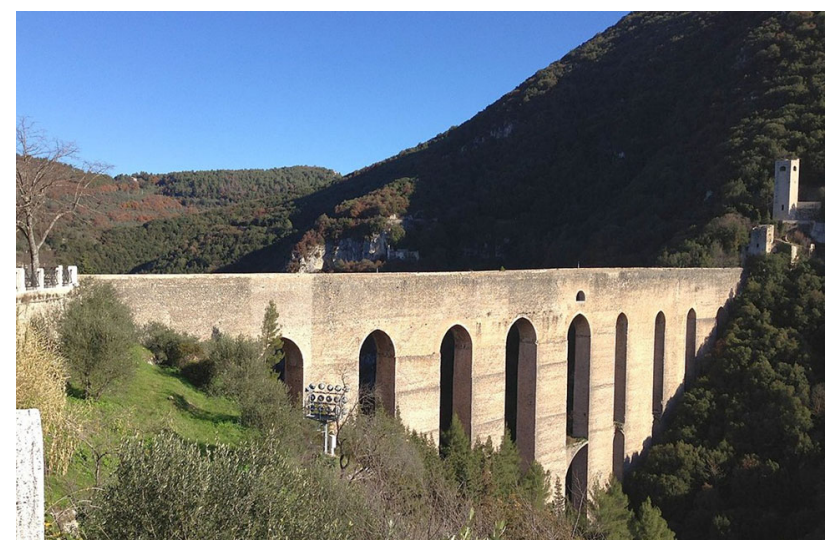

Fig. 8 The Ponte delle Torri at Spoleto, Italy [32]

Nazarian et al. [34] propose a methodology based on artificial intelligence. They introduced different Machine Learning approaches (the Support Vector Machines, the Neural Networks and the Gaussian Naïve Bayes) for assessment of damage in the structural elements in large buildings. The method utilizes bending strains obtained by loading of structural members to quantify and localize the

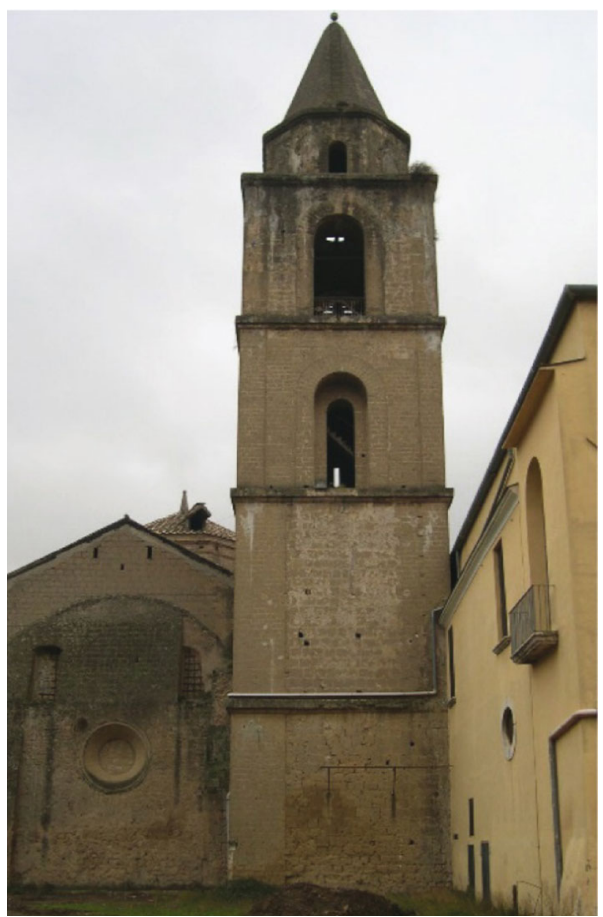

Fig. 9 External view of the Santa Maria a Vico bell-tower [33]

structural damage. The robustness of the methodology was evaluated by means of a numerical analysis, which ensured that the method is capable of identifying the location and intensity of damage with a prediction accuracy of over $86 \%$ and a sensors noise level within $8 \%$. The proposed approach was then used in the monitoring and experimentations of a historical building located in Chicago, Illinois, which was built in early 20th century (Fig. 10). The exterior of the building includes masonry columns and walls; the interior of the building utilizes pinned timber frames to support the gravitational loads. The structure was damaged because of the differential settlement of the foundation due to excavations adjacent to it.

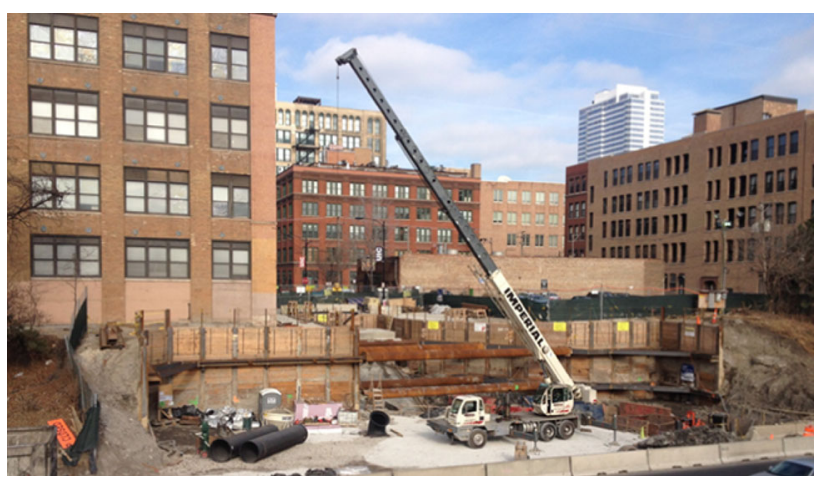

Fig. 10 The historical building at Chicago and excavations adjacent to it [34] 


\section{Conclusions}

Preservation of cultural heritage structures requires monetary investments that will immediately be paid off by tourism and, more importantly, transfer of cultural heritage to future generations. To achieve this, the public as well as the authorities in charge of such structures need to be convinced of the economic and cultural benefits associated with the preservation of historic structures.

In some cases, important interventions are necessary. These should be non-invasive and reversible and should aim at a balance between the needs of safety and the needs of preservation of the cultural testimony. But it is important to stress that "do nothing" is not a suitable solution. The collapse during the earthquake of October 30th, 2016, of the San Benedetto of Norcia Basilica, which had been damaged by the earthquake of August 24th, 2016, is a typical bad example.

Structural health monitoring appears to be the only way to guarantee this equilibrium, reducing the damage and planning the suitable interventions on time; in other words, to extend the life time of cultural heritage structures. The papers presented in this article and published in this Journal show some interesting cases, which are examples of good practise for the future.

\section{References}

1. Clemente P, Rinaldis D (1998) Protection of a monumental building against traffic-induced vibrations. Int J Soil Dyn Earth. Eng 17(5):289-296. https://doi.org/10.1016/s02677261(98)00012-8 (Elsevier Science Ltd)

2. Clemente P, Buffarini G (2009) Dynamic response of buildings of the cultural heritage. In: Boller C, Chang FK, Fujino Y (eds) Enciclopedia of structural health monitoring. Wiley, Chichester, pp 2243-2252 (ISBN 978-0-470-05822-0)

3. Clemente P, Rinaldis D, Buffarini G (2007) Experimental seismic analysis of a historical building. J Intel Mater Syst Struct 18(8):777-784. https://doi.org/10.1177/1045389x07074601 (SAGE Publications)

4. Bongiovanni G, Celebi M, Clemente P (1990) The Flaminio Obelisk in Rome: vibrational characteristics as part of preservation efforts. Int J Earth Eng Struct Dyn 19(1):107-118. https:// doi.org/10.1002/eqe.4290190110 (Wiley)

5. Clemente P, Bongiovanni G, Buffarini G (2002) Experimental analysis of the seismic behaviour of a cracked masonry structure. In: proc., 12th European conf. on earth. eng. (12ECEE, London 9-13 Sep), Paper 104, Elsevier Science Ltd

6. De Stefano A, Clemente P (2009) Structural health monitoring of historic buildings. In: Karbhari VM, Ansari F (eds) Structural health monitoring of civil infrastructure systems, cap, vol 13 . CRC Press, Boca Raton, pp 412-434

7. De Stefano A, Matta E, Clemente P (2016) Structural health monitoring of historical heritage in Italy: some relevant experiences. J Civil Struct Health Monit 6(1):83-106. https://doi.org/ 10.1007/s13349-016-0154-y (Springer)
8. Clemente P, Hailemikael S, Milana G, Orlando L (2017) Monitoring and seismic characterization of archaeological sites and structures-preface. Special Issue Ann Geophys 60(4):S0447. https://doi.org/10.4401/ag-7480

9. Cardarelli E, Cercato M, Orlando L (2017) Geometry and seismic characterization of the subsoil below the Amphitheatrum Flavium in Rome. Ann Geophys 60(4):S0436. https://doi.org/10.4401/ag7124 (INGV, Rome)

10. Orlando L, De Donno G, Di Giambattista L, Palladini L (2017) Investigating the foundation of the Amphitheatrum Flavium through the passage of Commodus. Ann Geophys 60(4):S0437. https://doi.org/10.4401/ag-7183 (INGV, Rome)

11. Hailemikael S, Milana G, Cara F, Vassallo M, Pischiutta M, Amoroso S, Bordoni P, Cantore L, Di Giulio G, Di Naccio D, Famiani D, Mercuri A (2017) Sub-surface characterization of the Amphitheatrum Flavium area in Rome through single-station ambient vibration measurements. Ann Geophys 60(4):S0438. https://doi.org/10.4401/ag-7359 (INGV, Rome)

12. Bongiovanni G, Buffarini G, Clemente P, Rinaldis D, Saitta F (2017) Dynamic characteristics of the Amphitheatrum Flavium northern wall from traffic-induced vibrations. Ann Geophys 60(4):S0439. https://doi.org/10.4401/ag-7178 (INGV, Rome)

13. Lorenzoni F, Casarin F, Modena C, Caldon M, Islami K, da Porto F (2013) Structural health monitoring of the Roman Arena of Verona, Italy. J Civil Struct Health Monit 3:227-246. https://doi. org/10.1007/s13349-013-0065-0 (Springer)

14. Bergamasco I, Carpani B, Clemente P, Papaccio V (2012) Seismic preservation of archeological sites: the case of Pompeii. In: Jasienko J (ed) Structural analysis of historical constructions (Proc. 8th Int. Conf. SAHC 2012, Wroclaw, 15-17 Oct), vol 2. Dolnośląskie Wydawnictwo Edukacyjne (DWE), Wroclaw, pp 1386-1394 (ISSN 0860-2395, ISBN 978-83-7125-216-7 (set), ISBN 978-83-7125-218-1 (Vol. 2))

15. Potenza F, Federici F, Lepidi M, Gattulli V, Graziosi F, Colarieti A (2015) Long-term structural monitoring of the damaged Basilica S. Maria di Collemaggio through a low-cost wireless sensor network. J Civil Struct Health Monit 5:655-676. https:// doi.org/10.1007/s13349-015-0146-3 (Springer)

16. Clemente P, Saitta F, Buffarini G, Platania L (2015) Stability and seismic analyses of leaning towers: the case of the minaret in Jam. Struct Des Tall Special Build 24:40-58. https://doi.org/10. 1002/tal.1153 (Wiley(on line 11 Feb 2014))

17. Zhao JH, Rivera E, Mufti A, Stephenson D, Thomson DJ (2012) Evaluation of dielectric based and other methods for moisture content measurement in building stones. J Civil Struct Health Monit 2:137-148. https://doi.org/10.1007/s13349-012-0024-1 (Springer)

18. Kurz JH (2015) Monitoring of timber structures. J Civil Struct Health Monit 5:97-98. https://doi.org/10.1007/s13349-014-00756 (Springer)

19. Cavalli A, Togni MJ (2015) Monitoring of historical timber structures: state of the art and prospective. J Civil Struct Health Monit 5:107-113. https://doi.org/10.1007/s13349-014-0081-8 (Springer)

20. Faggiano B, Grippa MR, Marzo A, Mazzolani FM (2011) Experimental study for non-destructive mechanical evaluation of ancient chestnut timber. J Civil Struct Health Monit 1:103-112. https://doi.org/10.1007/s13349-011-0011-y (Springer)

21. Talebinejad I, Fischer C, Ansari F (2011) A hybrid approach for safety assessment of the double span masonry vaults of the Brooklyn Bridge. J Civil Struct Health Monit 1:3-15. https://doi. org/10.1007/s13349-011-0003-y (Springer)

22. Banerji P, Chikermane S (2012) Condition assessment of a heritage arch bridge using a novel model updation technique. J Civil Struct Health Monit 2:1-16. https://doi.org/10.1007/s13349-0110013-9 (Springer) 
23. Mesquita E, Arêde A, Silva R, Rocha P, Gomes A, Pinto N, Antunes P, Varum H (2017) Structural health monitoring of the retrofitting process, characterization and reliability analysis of a masonry heritage construction. J Civil Struct Health Monit 7:405-428. https://doi.org/10.1007/s13349-017-0232-9 (Springer)

24. Clemente P (2017) Seismic isolation: past, present and the importance of SHM for the future. J Civil Struct Health Monit 7(2):217-231. https://doi.org/10.1007/s13349-017-0219-6 (Springer)

25. Clementi F, Pierdicca A, Formisano A, Catinari F, Lenci S (2017) Numerical model upgrading of a historical masonry building damaged during the 2016 Italian earthquakes: the case study of the Podestà palace in Montelupone (Italy). J Civil Struct Health Monit 7:703-717. https://doi.org/10.1007/s13349-017-0253-4 (Springer)

26. Bongiovanni G, Buffarini G, Clemente P, Rinaldis D, Saitta F (2017) Experimental vibration analyses of a historic tower structure. J Civil Struct Health Monit 7:601-613. https://doi.org/ 10.1007/s13349-017-0245-4 (Springer (on line 16 Oct 2017))

27. Salonikios T, Theodoulidis N, Morfidis K et al (2017) Efficiency investigation of structural interventions based on in situ ambient vibration measurements on Acheiropoietos Early Byzantine basilica, Thessaloniki, Greece. J Civil Struct Health Monit 8:135-149. https://doi.org/10.1007/s13349-017-0262-3 (Springer)

28. Sciarretta F, Antonelli F, Peron F et al (2018) Final outcomes on the multi-disciplinary long-term monitoring and preservation state investigation on the medieval external Façades of Palazzo
Ducale in Venice, Italy. J Civil Struct Health Monit 8:111-133. https://doi.org/10.1007/s13349-017-0263-2 (Springer)

29. Saisi A, Gentile C, Ruccolo A (2017) Continuous monitoring of a challenging heritage tower in Monza, Italy. J Civil Struct Health Monit 8:77-90. https://doi.org/10.1007/s13349-017-0260-5 (Springer)

30. Lorenzoni F, Caldon M, da Porto F, Modena C, Takayoshi A (2017) Post-earthquake controls and damage detection through structural health monitoring: applications in l'Aquila. J Civil Struct Health Monit. https://doi.org/10.1007/s13349-018-0270-y (Springer)

31. Bergamasco I, Marzo A, Marghella G, Carpani B (2017) In-situ experimental campaign of the covering on the structures of Villa dei Misteri in Pompeii. J Civil Struct Health Monit. https://doi. org/10.1007/s13349-018-0274-7 (Springer)

32. Roselli I, Malena M, Mongelli M, Cavalagli N, Gioffrè M, De Canio G, de Felice G (2017) Structural health monitoring by ambient vibration testing of the Ponte delle Torri of Spoleto during the 2016-2017 Central Italy seismic sequence. J Civil Struct Health Monit. https://doi.org/10.1007/s13349-018-0268-5 (Springer)

33. Ferraioli M, Miccoli L, Abruzzese D (2017) Dynamic characterization of a historic bell-tower using a sensitivity-based technique for model tuning. J Civil Struct Health Monit. https://doi. org/10.1007/s13349-018-0272-9 (Springer)

34. Nazarian E, Todd T, Weifeng T, Ansari F (2018) Machine learning based approach for post event assessment of damage in a turn-of-the-century building structure. J Civil Struct Health Monit. https://doi.org/10.1007/s13349-018-0275-6 (Springer) 